\title{
Acute dislocation of fully deployed stent after use of non-compliant balloon: an enigma
}

\author{
Ostre przemieszczenie całkowicie rozprężonego stentu \\ po użyciu niezgodnego balonu
}

\author{
Santosh Kumar Sinha, Mahmadulla Razi, Ramesh Thakur, Mukesh Jitendra Jha, Amit Goel, \\ Vikas Mishra, Ashutosh Kumar
}

Department of Cardiology, L.P.S. Institute of Cardiology G.S.V.M. Medical College, Kanpur, Uttar Pradesh, India

\begin{abstract}
Stent embolism is an established but rare complication of percutaneous coronary intervention, usually encountered when an undeployed stent unintentionally dislocates from the balloon. Published literature regarding incidence or clinical outcomes of embolism of fully deployed coronary stents is sparse. Here we report an unusual case of a 41-year-old male who had dislocation of a fully deployed stent into the distal part of left anterior descending artery following post dilatation by non-compliant balloon during percutaneous coronary intervention.
\end{abstract}

Key words: left anterior descending artery, dislocation of deployed stent, non-compliant balloon

Folia Cardiologica 2016; 11, 3: 222-225

\section{Introduction}

Although percutaneous coronary intervention has become an established and effective modality, some undesirable events such as stent embolization may still occur. Although a rarity, stent embolization may lead to devastating consequences such as acute closure of the affected vessel, coronary thrombosis, myocardial infarction and sudden cardiac death [1]. Majority of cases involve balloon expandable stent dislodgement from its delivery system during deployment or migration of a fractured part of coronary stent. Acute dislocation of a fully deployed stent is something that is extreme of rarity.

\section{Case report}

A 41-year-old male was admitted with acute coronary syndrome: ST-elevation myocardial infarction (STEMI). Smoking and hypertension were his cardiac risk factors. His ECG showed normal sinus rhythm with ST $\uparrow \geq 5 \mathrm{~mm}$ in $\mathrm{V}_{2-5}$ with reciprocal changes in inferior leads. His was haemodynamically stable. Routine investigations were normal. Echocardiogram revealed mild hypokinesia in LAD Tx with EF 48\%. He was thrombolysed by Tenecteplase on weight based regimen. After one hour, he experienced three episodes of sustained ventricular tachycardia VT for which he was cardioverted with $200 \mathrm{~J}$. He developed transient complete heart block for which temporary pacing lead was put. On the next day, coronary angiogram (CAG) was performed with intent to intervention as a part of pharmaco-invasive strategy. CAG revealed a critical stenotic lesion (90\%) of the mid left anterior descending artery (LAD) with other arteries being normal (Fig. 1). Percutaneous coronary intervention $(\mathrm{PCl})$ was planned for the significant lesion of LAD artery. A 6 Fr Extra Back Up (EBU) 3.5 Launcher guide catheter (Medtronic, USA) was used to engage the LAD and the diseased segment was crossed with a Balanced Middle weight (BMW) 0.014" wire (Abbott, USA). 


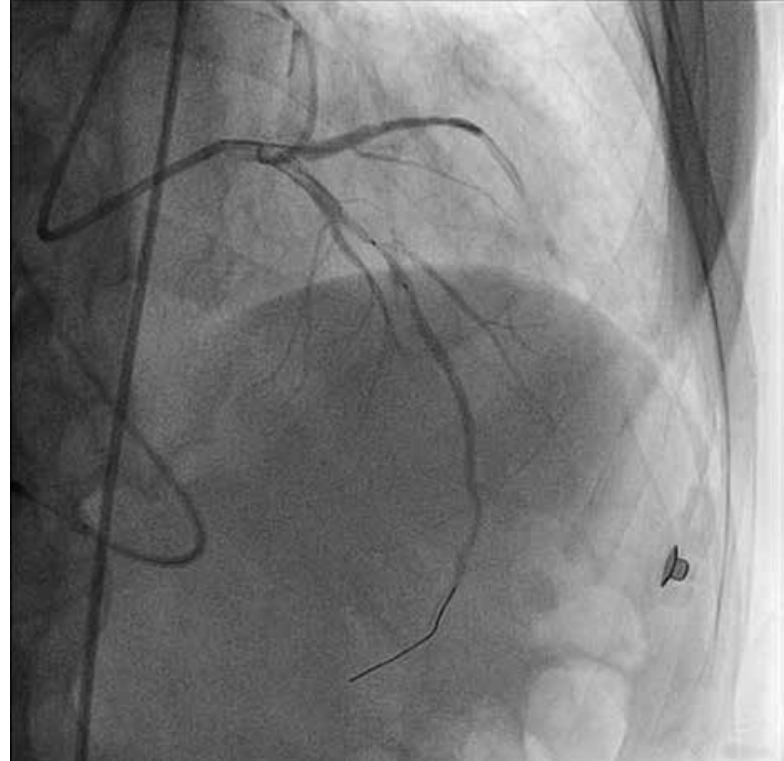

Figure 1. Critical stenotic lesion (90\%) of mid left anterior descending artery (LAD) and pre-dilatation with semi-compliant balloon
The lesion was pre-dilated with a $1.5 \times 10$ and $2.0 \mathrm{~mm} \times$ $\times 10 \mathrm{~mm}$ Mini track balloon (Abbott, USA), and intracoronary glyceryl trinitrate was administered at a recommended dose $(100 \mu \mathrm{g})$ in order to resolve distal coronary vasospasm and sizing assessment $3 \mathrm{~mm} \times 38 \mathrm{~mm}$ (Fig. 1). Resolute Integrity drug-eluting stent (Medtronic, USA) was deployed in the mid LAD to 12 atmospheres (Fig. $2 A-C$ ). Stent was further post dilated with a $3.5 \mathrm{~mm} \times 10 \mathrm{~mm}$ NC Track balloon (Abbott, USA) to 18 atmospheres (Fig, 2D). Following post-dilatation, we examined carefully and noticed that the stent had migrated little forward (Fig. 3, 4). The patient was asymptomatic. Neither the residual lesion at the site where we deployed the stent initially neither was significantly stenotic anymore nor was any dissection present. After considering the risks/benefits of conservative management vs. further percutaneous intervention and as there was TIMI III flow, it was decided not to intervene further (Fig. 5). Patient was shifted to the coronary care unit and discharged in stable condition with appropriate advice after three days. He is under regular follow up since then.
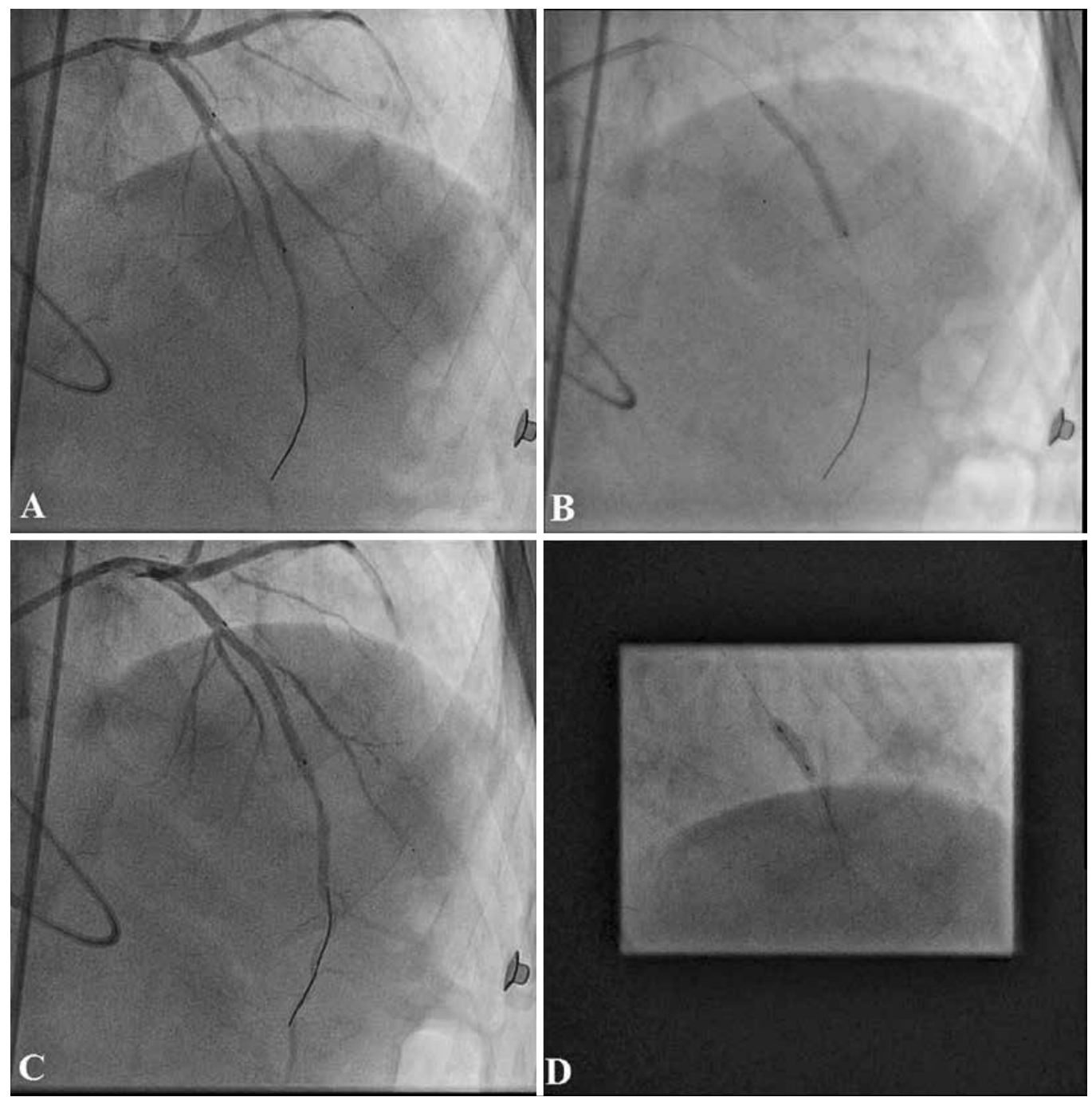

Figure 2A-D. Stent pre-deployment (A), stent during deployment (B), post-deployment (C), post dilatation by non-compliant balloon (D) 


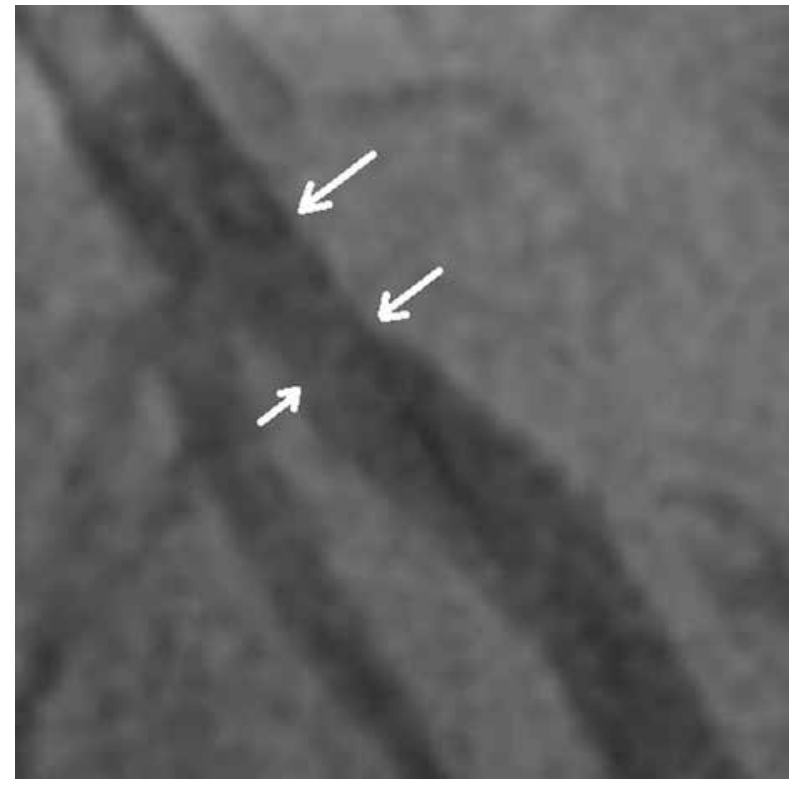

Figure 3. Stent dislocation - proximal edge after deployment (single arrow) and after dilation by non-compliant balloon (double arrow)

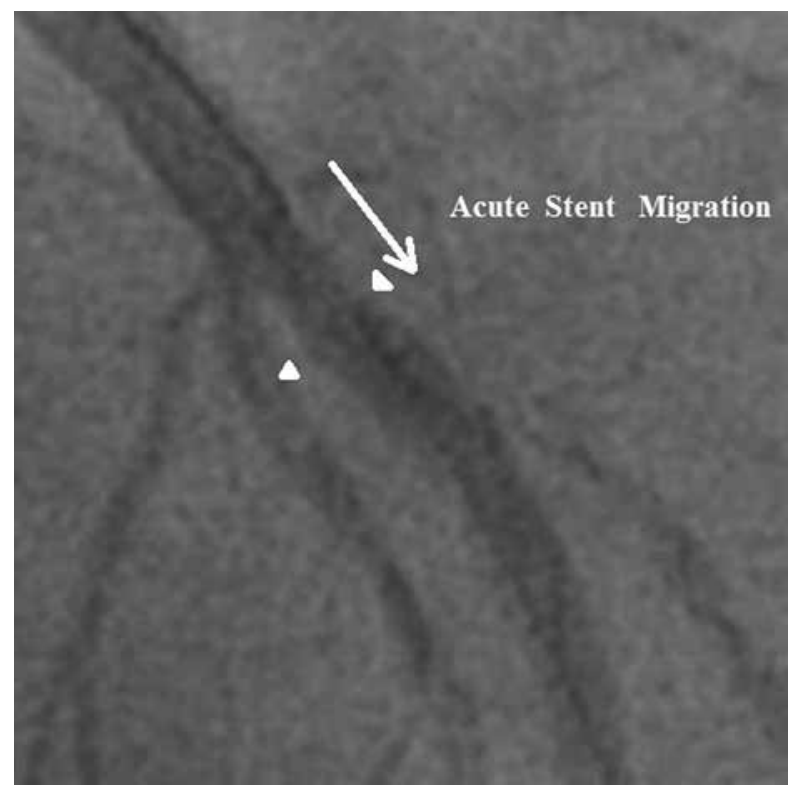

Figure 4. Acute stent migration as it had migrated little forward

\section{Discussion}

Coronary stent embolism occurs when a coronary stent is inadvertently dislodged into the coronary tree. The incidence of stent embolism has been reported to be in the region of $0.32 \%$ to $8.4 \%$ [2]. The vast majority of reported cases involve undeployed stents dislodging from the balloon, and this problem is most commonly encountered when treating severely calcified lesions, angulated lesions, under-expanded stents, small short stents, primary sten-

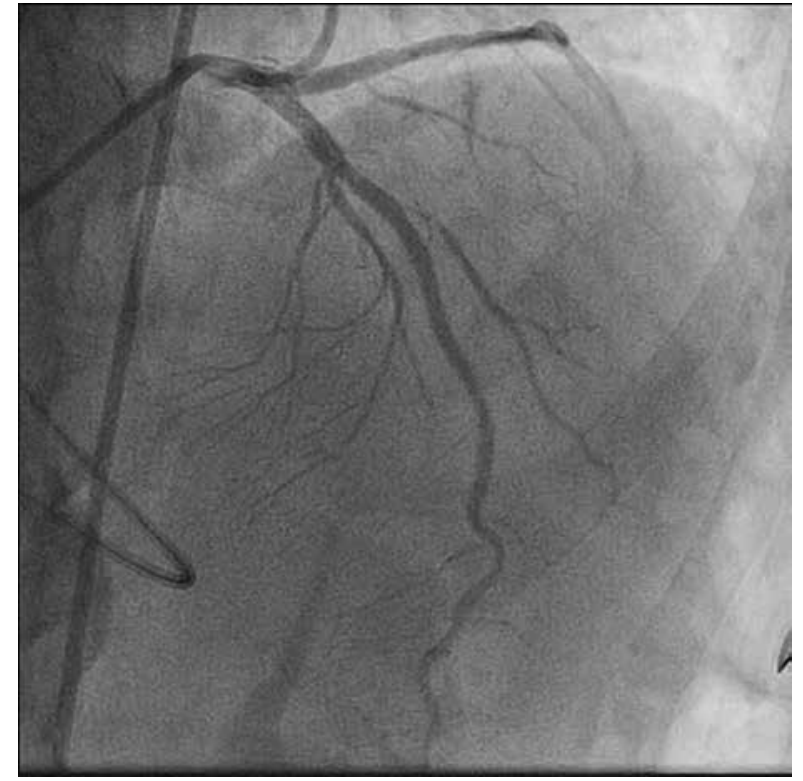

Figure 5. Final position with TIMI III flow

ting, manual handling of the stent, and stent type [3-5], Premounting technology also affects the incidence of this type of stent embolism [6, 7]. However, migration of fully deployed stent is exceedingly rare, but has the potential to cause significant events such as acute closure or stroke [8]. In view of showing the migration of deployed stent after use of non-compliant balloon, our case report is the first in literature to the best of our knowledge. Though the exact mechanism of migration was elusive, we suspect that the main reason for migration of deployed stent was either underestimation of vessel diameter or the improper embedding of stent struts at all into the arterial wall. Intracoronary glyceryl trinitrate administration may have been a contributing factor. The immediate effect of stenting on micro vascular endothelial function is one of factors for promoting vasoconstriction. There is a down-regulation of endothelial nitric oxide synthase (eNOS), and increased release of the vasoconstrictors serotonin and endothelin 1 in a vessel exposed to low shear stress [9]. Glyceryl trinitrate by releasing nitric oxide acts as a potent vasodilator. Subsequently, when intracoronary glyceryl trinitrate was administered, the stent may have had migrated distally. Either acute closure, coronary thrombosis, dissection were not present and TIMI III flow was there; thus, conservative strategy was adopted. Therefore, interventional cardiologists should not give up the possibility of migration of stent deployed successfully during PCls.

\section{Conflict of interest(s)}

None declared. 


\section{Streszczenie}

Zator spowodowany stentem to znane, lecz rzadkie powikłanie przezskórnej interwencji wieńcowej, występujące zwykle w sytuacji, gdy nierozprężony stent przypadkowo zsunie się z balonu. Niewiele jest doniesień dotyczących częstości lub skutków klinicznych zatoru w pełni rozprężonym stentem wieńcowym. Autorzy przedstawiają nietypowy przypadek 41-letniego chorego, u którego nastąpiło przemieszczenie całkowicie rozprężonego stentu do dystalnej części tętnicy przedniej zstępującej lewej po rozszerzeniu niezgodnym balonem w trakcie przezskórnej interwencji wieńcowej.

Słowa kluczowe: tętnica przednia zstępująca lewa, przemieszczenie rozprężonego stentu, niezgodny balon

Folia Cardiologica 2016; 11, 3: 222-225

\section{References}

1. Breaks E.S., Best P.J., Elesber A.A. et al. Incidence, retrieval methods, and outcomes of stent loss during percutaneous coronary intervention: a large single-center experience. Catheter. Cardiovasc. Interv. 2005; 66: 333-340.

2. Joost A., Hunold P., Weil J. Intraventricular stent loss after interventional treatment of a coronary dissection-a case report. J. Invasive Cardiol. 2011; 23: E211-E213.

3. Kozman H., Wiseman A.H., Cook J.R. Long-term outcome following coronary stent embolization or misdeployment. Am. J. Cardiol. 2001; 88: 630-634.

4. Eggebrecht H., Haude M., von Birgelen C. et al. Nonsurgical retrieval of embolized coronary stents. Catheter. Cardiovasc. Interv. 2000; 51: 432-440.

5. Bolte J., Neumann U., Pfafferott C. et al. Incidence, management, and outcome of stent loss during intracoronary stenting. Am. J. Cardiol. 2001; 88: 565-567.
6. Lohavanichbutr K., Webb J.G., Carere R.G. et al. Mechanisms, management, and outcome of failure of delivery of coronary stents. Am. J. Cardiol. 1999; 83: 779-781.

7. Saleh L., Movahed M.R. Successful conservative treatment of an undeployed embolized intracoronary stent with dual antiplatelet and warfarin therapy. Exp. Clin. Cardiol. 2010; 15: e70-e72.

8. Mamopoulos A., Nowak T., Klues H., Luther B. Late coronary ostial stent fracture and embolisation causing an acute thrombotic occlusion of the carotid artery with cerebral infarction. Circ. Cardiovasc. Interv. 2012; 5: e76-e78.

9. Hasdai D., Holmes D.R. Jr., Garratt K.N. et al. Mechanical pressure and stretch release endothelin-1 from human atherosclerotic coronary arteries in vivo. Circulation 1997; 95: 357-362. 